\title{
Traumatic brain injury may not increase the risk of Alzheimer disease OPEN
}

Michael W. Weiner, MD*

Paul K. Crane, MD, $\mathrm{MPH}^{*}$

Thomas J. Montine, MD, PhD*

David A. Bennett, MD*

Dallas P. Veitch, PhD

Correspondence to

Dr. Weiner:

michael.weiner@ucsf.edu

\section{ABSTRACT}

Traumatic brain injury (TBI) commonly occurs in civilian and military populations. Some epidemiologic studies previously have associated TBI with an increased risk of Alzheimer disease (AD). Recent clinicopathologic and biomarker studies have failed to confirm the relationship of TBI to the development of AD dementia or pathologic changes, and suggest that other neurodegenerative processes might be linked to TBI. Additional studies are required to determine the long-term consequences of TBI. Neurology ${ }^{\circledR}$ 2017;89:1923-1925

\section{GLOSSARY}

$\mathbf{A} \boldsymbol{\beta}=\beta$-amyloid $\mathbf{A D}=$ Alzheimer disease $; \mathbf{P D}=$ Parkinson disease; $\mathbf{T B I}=$ traumatic brain injury.

Traumatic brain injury (TBI) is a common injury sustained through military service, sports involvement, falls, or other accidents. The Centers for Disease Control and Prevention reported that in 2013 there were 2.5 million emergency department visits and 282,000 hospitalizations related to TBI in the United States. More than $40 \%$ of participants in a recent study reported a lifetime history of either mild or moderate to severe TBI. ${ }^{1}$ In active duty US Army members, the overall annual incidence rate of TBI increased from 786 to 2,718 per 100,000 from 2003 to 2011 (cdc.gov/traumaticbraininjury/data/). Increased media coverage of sports and military TBIs has highlighted the profound effect these injuries have on individuals and their families. In addition to short-term cognitive impairment following injury, long-term cognitive functioning is impaired in as many as $65 \%$ of patients with moderate to severe TBI. ${ }^{2}$ However, the exact nature of the effect on the aging brain has not been well-defined. ${ }^{3,4}$

Alzheimer disease $(\mathrm{AD})$, a $\beta$-amyloid $(\mathrm{A} \beta)$-facilitated tauopathy, has been considered a possible pathologic outcome of TBI; amyloid precursor protein, the parent protein of $A \beta$, is a commonly used immunohistochemical marker of diffuse axonal injury following TBI, especially in white matter ${ }^{5}$; and $A \beta$ has been found in the brains of young decedents following a single severe TBI. ${ }^{6,7}$ Therefore numerous epidemiologic studies have examined the link between TBI and AD. The majority of these studies (reviewed in reference 8) reported that TBI elevated the risk for developing $\mathrm{AD}$. Indeed, many ranked TBI only after age, family history, and $A P O E$ genotype in importance as an $\mathrm{AD}$ risk factor. ${ }^{9}$ Some reported an interaction between these risk factors: the risk of AD from TBI was higher in carriers of the $A P O E \& 4$ risk alleles than in noncarriers, ${ }^{10-14}$ and higher in male than in female participants. A comprehensive consensus analysis of this literature further bolstered TBI as an $\mathrm{AD}$ risk factor, concluding that in men, TBI more than doubled the risk of future development of $\mathrm{AD}$ (odds ratio 2.29 [confidence interval 1.47-3.58]). ${ }^{15}$

Almost all epidemiologic studies of the relationship between TBI and AD have 2 major limitations. First, most have used self-report information to determine a history of TBI exposure.

\footnotetext{
*These authors contributed equally to this work.

From the Department of Veterans Affairs Medical Center (M.W.W., D.P.V.), Center for Imaging of Neurodegenerative Diseases, San Francisco, CA; Department of Medicine (P.K.C.), University of Washington, Seattle; Department of Pathology (T.J.M.), Stanford University School of Medicine, Palo Alto, CA; and Department of Neurological Sciences (D.A.B.), Rush University Medical Center, Chicago, IL.

Go to Neurology.org for full disclosures. Funding information and disclosures deemed relevant by the authors, if any, are provided at the end of the article. The Article Processing Charge was funded by DOD ADNI (Department of Defense; Alzheimer's Disease Neuroimaging Initiative).

This is an open access article distributed under the terms of the Creative Commons Attribution-NonCommercial-NoDerivatives License 4.0 (CC BY-NC-ND), which permits downloading and sharing the work provided it is properly cited. The work cannot be changed in any way or used commercially without permission from the journal.
} 
While the collection of exposure information before the onset of dementia may be a valid approach, collection of exposure data from people who are already cognitively impaired has obvious drawbacks in the reliability of the data. Second, most studies have relied on billing codes for clinical diagnosis of $\mathrm{AD}$ dementia rather than using an array of recently developed biomarkers or neuropathologic examination.

These limitations were overcome in 2 recent studies examining the relationship between TBI and AD. In one report, the self-reported TBI, with more than 1 hour loss of consciousness, was collected at a time when participants were cognitively intact. The late effects of this TBI were investigated in 3 large community-based cohort studies on brain aging and dementia-the Religious Orders Study, the Memory and Aging Project, and the Adult Changes in Thought study - that ask participants to donate their brains for research. ${ }^{16}$ Of 7,130 participants, 1,589 underwent brain autopsy over the 20-year period from 1994 to 2014. This report focused on the spectrum of common agerelated diseases of the brain including $\mathrm{AD}$, vascular brain injury, hippocampal sclerosis, and Parkinson disease (PD) and its pathologic hallmark, Lewy body disease. Pooled analysis showed that a history of TBI with loss of consciousness was not associated with $\mathrm{AD}$ dementia or the neuropathologic features of $\mathrm{AD}$; rather it was associated with Lewy body disease, PD, and progression of parkinsonism. Unlike some epidemiologic studies, wellpowered analyses did not find interactions between clinical or neuropathologic $\mathrm{AD}$ outcomes for TBI and the APOE $\varepsilon 4$ genotype or sex.

A second report used Veterans Administration medical records to document a history of TBI and established AD biomarkers to measure $\mathrm{AD}$ pathology. The study investigated the extent to which a history of TBI increases the odds of developing cognitive impairments or changes in $\mathrm{AD}$ biomarkers, which included structural brain changes on MRI and $A \beta$ deposition measured by florbetapir PET scans. The results showed no effects of TBI history on cognition or $\mathrm{AD}$ biomarkers. ${ }^{17}$
These data fail to support TBI as a risk factor for developing AD dementia. Both studies circumvented the limitation of self-reported TBI in cognitively impaired participantsone used self-reported TBI with loss of consciousness collected at a time when participants were known to be cognitively intact, ${ }^{16}$ and the other used medical records information to document TBI exposure. ${ }^{17}$ Likewise, neither study relied solely on clinical diagnosis of dementia and $\mathrm{AD}$, but augmented diagnosis with neuropathology evaluations ${ }^{16}$ or MRI and florbetapir PET scans. ${ }^{17}$

These large, well-powered, and carefully conducted studies cast substantial doubt on the association between TBI exposure and $\mathrm{AD}$ outcomes, both overall and among men and carriers of $A P O E \& 4$ alleles. What then are the long-term implications of TBI exposure? The association of TBI with PD neuropathology ${ }^{16}$ suggests that TBI exposure is not innocuous and is consistent with a recent large epidemiologic study that found an increased risk of PD following late life TBI. ${ }^{18}$ Neuropathologic outcomes appear to differ depending on the severity or frequency of the TBI. ${ }^{4}$ Further investigation is clearly needed to determine the relationship of TBI to cognitive decline in the elderly in order to effectively address this serious public health problem.

\section{AUTHOR CONTRIBUTIONS}

Dr. Weiner: view concept, critical revision of manuscript for intellectual content. Dr. Crane: view concept, critical revision of manuscript for intellectual content. Drs. Montine and Bennett: view concept, critical revision of manuscript for intellectual content. Dr. Veitch: drafting and revision of manuscript.

\section{STUDY FUNDING}

No targeted funding reported.

\section{DISCLOSURE}

M. Weiner receives grants from the Department of Defense titled "The effects of TBI and PTSD on the development of AD in Vietnam veterans studied with ADNI." P. Crane, T. Montine, D. Bennett, and D. Veitch report no disclosures relevant to the manuscript. Go to Neurology.org for full disclosures.

Received May 15, 2017. Accepted in final form August 8, 2017.

\section{REFERENCES}

1. Whiteneck GG, Cuthbert JP, Corrigan JD, Bogner JA. Prevalence of self-reported lifetime history of traumatic brain injury and associated disability: a statewide population-based survey. J Head Trauma Rehabil 2016; 31:E55-E62. 
2. Rabinowitz AR, Levin HS. Cognitive sequelae of traumatic brain injury. Psychiatr Clin North Am 2014;37: $1-11$.

3. Manley GT, Maas AI. Traumatic brain injury: an international knowledge-based approach. JAMA 2013;310: 473-474.

4. Washington PM, Villapol S, Burns MP. Polypathology and dementia after brain trauma: does brain injury trigger distinct neurodegenerative diseases, or should they be classified together as traumatic encephalopathy? Exp Neurol 2016;275:381-388.

5. Sherriff FE, Bridges LR, Sivaloganathan S. Early detection of axonal injury after human head trauma using immunocytochemistry for beta-amyloid precursor protein. Acta Neuropathol 1994;87:55-62.

6. Roberts GW, Gentleman SM, Lynch A, Murray L, Landon $\mathrm{M}$, Graham DI. Beta amyloid protein deposition in the brain after severe head injury: implications for the pathogenesis of Alzheimer's disease. J Neurol Neurosurg Psychiatry 1994;57:419-425.

7. Uryu K, Chen XH, Martinez D, et al. Multiple proteins implicated in neurodegenerative diseases accumulate in axons after brain trauma in humans. Exp Neurol 2007; 208:185-192.

8. Jellinger KA. Head injury and dementia. Curr Opin Neurol 2004;17:719-723.

9. Daviglus ML, Plassman BL, Pirzada A, et al. Risk factors and preventive interventions for Alzheimer disease: state of the science. Arch Neurol 2011;68:1185-1190.

10. Lichtman S, Seliger G, Tycko B, Marder K. Apolipoprotein $\mathrm{E}$ and functional recovery from brain injury following postacute rehabilitation. Neurology 2000;55:1536-1539.
11. Jellinger K, Paulus W, Wrocklage C, Litvan I. Effects of closed traumatic brain injury and genetic factors on the development of Alzheimer's disease. Eur J Neurol 2001;8: 707-710.

12. Diaz-Arrastia R, Gong Y, Fair S, et al. Increased risk of late posttraumatic seizures associated with inheritance of APOE $\varepsilon 4$ allele. Arch Neurol 2003;60:818-822.

13. Ariza M, Pueyo R, Matarín Mdel M, et al. Influence of APOE polymorphism on cognitive and behavioural outcome in moderate and severe traumatic brain injury. J Neurol Neurosurg Psychiatry 2006;77:1191-1193.

14. Houlden H, Greenwood R. Apolipoprotein E4 and traumatic brain injury. J Neurol Neurosurg Psychiatry 2006; 77:1106-1107.

15. Fleminger S, Oliver DL, Lovestone S, Rabe-Hesketh S, Giora A. Head injury as a risk factor for Alzheimer's disease: the evidence 10 years on; a partial replication. J Neurol Neurosurg Psychiatry 2003;74:857-862.

16. Crane PK, Gibbons LE, Dams-O'Connor K, et al. Association of traumatic brain injury with late-life neurodegenerative conditions and neuropathologic findings. JAMA Neurol 2016;73:1062-1069.

17. Weiner MW, H D, Hayes J, et al; Department of Defense Alzheimer's Disease Neuroimaging Initiative. Effects of traumatic brain injury and posttraumatic stress disorder on development of Alzheimer's disease in Vietnam veterans using the Alzheimer's Disease Neuroimaging Initiative: preliminary report. Alzheimer Dement 2017;3:177-188.

18. Gardner RC, Burke JF, Nettiksimmons J, Goldman S, Tanner CM, Yaffe K. Traumatic brain injury in later life increases risk for Parkinson disease. Ann Neurol 2015;77: 987-995. 


\section{Neurology}

\section{Traumatic brain injury may not increase the risk of Alzheimer disease Michael W. Weiner, Paul K. Crane, Thomas J. Montine, et al. \\ Neurology 2017;89;1923-1925 Published Online before print October 4, 2017 DOI 10.1212/WNL.0000000000004608}

This information is current as of October 4, 2017

\section{Updated Information \& Services}

\section{References}

Citations

Subspecialty Collections

Permissions \& Licensing

Reprints including high resolution figures, can be found at: http://n.neurology.org/content/89/18/1923.full

This article cites 18 articles, 5 of which you can access for free at: http://n.neurology.org/content/89/18/1923.full\#ref-list-1

This article has been cited by 1 HighWire-hosted articles: http://n.neurology.org/content/89/18/1923.full\#\#otherarticles

This article, along with others on similar topics, appears in the following collection(s):

\section{Alzheimer's disease}

http://n.neurology.org/cgi/collection/alzheimers_disease

Assessment of cognitive disorders/dementia

http://n.neurology.org/cgi/collection/assessment_of_cognitive_disorder S_dementia

\section{Brain trauma}

http://n.neurology.org/cgi/collection/brain_trauma

MRI

http://n.neurology.org/cgi/collection/mri

PET

http://n.neurology.org/cgi/collection/pet

Information about reproducing this article in parts (figures,tables) or in its entirety can be found online at:

http://www.neurology.org/about/about_the_journal\#permissions

Information about ordering reprints can be found online:

http://n.neurology.org/subscribers/advertise

Neurology ${ }^{\circledR}$ is the official journal of the American Academy of Neurology. Published continuously since 1951, it is now a weekly with 48 issues per year. Copyright Copyright ( 2017 The Author(s). Published by Wolters Kluwer Health, Inc. on behalf of the American Academy of Neurology.. All rights reserved. Print ISSN: 0028-3878. Online ISSN: 1526-632X.

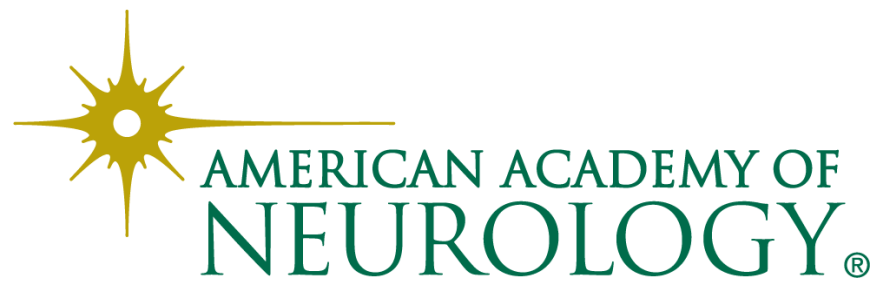

